\title{
Chlorogenic acid attenuates hydrogen peroxide-induced oxidative stress in lens epithelial cells
}

\author{
JIKE SONG $^{1}$, DADONG GUO ${ }^{2}$ and HONGSHENG BI ${ }^{2}$ \\ ${ }^{1}$ Medical College of Ophthalmology and Optometry, Shandong University of Traditional Chinese Medicine; ${ }^{2}$ Shandong \\ Provincial Key Laboratory of Integrated Traditional Chinese and Western Medicine for Prevention and Therapy of Ocular Diseases; \\ Eye Institute of Shandong University of Traditional Chinese Medicine, Jinan, Shandong 250002, P.R. China
}

Received October 4, 2016; Accepted November 27, 2017

DOI: $10.3892 /$ ijmm.2017.3302

\begin{abstract}
Oxidative stress has an important role in the degradation, oxidation, cross-linking and aggregation of lens proteins, and can trigger lens epithelial cell apoptosis. To investigate the protective effect of chlorogenic acid (CGA) against hydrogen peroxide $\left(\mathrm{H}_{2} \mathrm{O}_{2}\right)$-induced oxidative stress, human lens epithelial cells (hLECs) were exposed to various concentrations of $\mathrm{H}_{2} \mathrm{O}_{2}$ in the presence and absence of CGA. Using MTT assay, reverse transcription-quantitative polymerase chain reaction (RT-qPCR) and ELISA techniques, cell viability, and protein/mRNA levels of BCL2 apoptosis regulator (Bcl-2) and BCL2 associated X apoptosis regulator (Bax) were investigated. Additionally, the levels of intracellular reactive oxygen species (ROS) and apoptosis within cells were measured using flow cytometry to determine the protective effect of $\mathrm{CGA}$ on $\mathrm{H}_{2} \mathrm{O}_{2}$-induced oxidative stress. Furthermore, the protective effect of CGA on $\mathrm{H}_{2} \mathrm{O}_{2}$-induced apoptosis was also examined using rabbit lenses ex vivo. The results indicated that CGA reduced $\mathrm{H}_{2} \mathrm{O}_{2}$-induced cytotoxicity in a dose-dependent manner. Flow cytometry analysis demonstrated that simultaneous exposure of hLECs to $\mathrm{H}_{2} \mathrm{O}_{2}$ and CGA significantly decreased apoptosis and the levels of ROS. RT-qPCR analysis revealed a decrease in Bcl-2 and an increase in Bax in hLECs following exposure to $\mathrm{H}_{2} \mathrm{O}_{2}$ for $24 \mathrm{~h}$, regardless of CGA presence. Furthermore, ELISA results indicate that CGA increased Bcl-2 expression and decreased Bax expression following treatment with $\mathrm{H}_{2} \mathrm{O}_{2}$ for $24 \mathrm{~h}$ and the $\mathrm{Bax} / \mathrm{Bcl}-2$ ratio was significantly decreased by CGA treatment. Lens organ culture experiments indicated a dose-dependent decrease in $\mathrm{H}_{2} \mathrm{O}_{2}$-induced lens opacity following CGA treatment. These results suggest that CGA suppresses hLECs apoptosis and prevents lens opacity induced by $\mathrm{H}_{2} \mathrm{O}_{2}$ via $\mathrm{Bax} / \mathrm{Bcl}-2$ signaling pathway. CGA may provide effective defenses against oxidative
\end{abstract}

Correspondence to: Professor Hongsheng Bi, Shandong Provincial Key Laboratory of Integrated Traditional Chinese and Western Medicine for Prevention and Therapy of Ocular Diseases Eye Institute of Shandong University of Traditional Chinese Medicine, 48 Yingxiongshan Road, Jinan, Shandong 250002, P.R. China

E-mail: azuresky1999@163.com

Key words: chlorogenic acid, hydrogen peroxide, oxidative stress, lens epithelial cell, lens opacity stress and, thus, hao potential as treatment for a variety of diseases in clinical practice.

\section{Introduction}

Human lens epithelium is the most metabolically active cell layer of the lens, and is the initial cell layer exposed to environmental and oxidative insult (1). Oxidative stress has an important role in the degradation, oxidation, cross-linking and aggregation of lens proteins, and also triggers lens epithelial cell apoptosis. The apoptosis of lens epithelial cells has been proposed as a common basis for the initiation of noncongenital cataract formation, with oxidative stress as a major contributor to cataract formation (2-4). Exposure to oxidative stress results in lens opacification in experimental animal models $(5,6)$ and cultured lens systems (7-9).

Hydrogen peroxide $\left(\mathrm{H}_{2} \mathrm{O}_{2}\right)$ is one of the most physiologically relevant oxidants of the lens and aqueous humor, and has been reported to deplete glutathione and damage ion pump activity in lens epithelial cells (LECs) $(10,11)$. Elevated levels of $\mathrm{H}_{2} \mathrm{O}_{2}$ are reported in the aqueous humor of patients with cataract and can lead to opacification of the lens in vitro $(12,13)$. Overall, previous studies have demonstrated that $\mathrm{H}_{2} \mathrm{O}_{2}$-induced apoptosis in human lens epithelium cells is a useful model of cataractogenesis (14-16).

It has been confirmed that loss of transparency during human cataract formation is involved in a variety of complex metabolic and physiologic mechanisms, and an increase in antioxidant levels in the lens may prevent or ameliorate oxidative damage, and reduce cataract risk (7). Therefore, it is important to develop protective strategies against apoptosis in human lens epithelial cells to prevent cataractogenesis.

Chlorogenic acid (CGA) is one of the most abundant polyphenol compounds in coffee, strawberries, pineapple, apple, sunflower and blueberries (17). The molecular structure of CGA is presented in Fig. 1. It can exert various biological properties and modulatory effects on lipid and glucose metabolism under metabolic dysregulation conditions, such as antioxidant, antiangiogenic, anticarcinogenic and antiglycation (18-21). Kim et al (22) reported that CGA may provide a potential therapeutic approach for prevention of diabetic complications, such as cataracts. Akila et al (23) reported that CGA is an effective protective agent to maintain the activities of enzymic antioxidants, including superoxide dismutase, catalase, glutathione peroxidase and glutathione-S-transferase. Similarly, 
Ye et al (24) demonstrated that CGA efficiently protected kidney function against oxidative stress in a rat model of diabetic nephropathy.

Based on these observations, we hypothesize that CGA may protect human lens epithelial cells (hLECs) against oxidative stress-induced apoptosis, and may offer benefits in the treatment of cataract associated with oxidative stress. In the present study, $\mathrm{H}_{2} \mathrm{O}_{2}$-treated hLECs and rabbit lenses were used as models to examine the protective effect of CGA on LECs exposed to $\mathrm{H}_{2} \mathrm{O}_{2}$-mediated oxidative stress.

\section{Materials and methods}

Materials. Human HLE-B3 lens epithelial cell line was obtained from the American Type Culture Collection (Manassas, VA, USA), and chlorogenic acid (purity, 98.7\%) was purchased from the National Institute for the Control of Pharmaceutical and Biological Products of China (Beijing, China). MTT and $\mathrm{H}_{2} \mathrm{O}_{2}(30 \%)$ were purchased from Sigma-Aldrich (Merck KGaA, Darmstadt, Germany). A $500 \mu \mathrm{M} \mathrm{H}_{2} \mathrm{O}_{2}$ solution was prepared in phosphate-buffered saline (PBS) immediately prior to application. The Annexin V/propidium iodide (PI) apoptotic detection kit was purchased from Nanjing KeyGen Biotech Co., Ltd. (Nanjing, China). All other chemicals used were purchased from Sigma-Aldrich (Merck KGaA) unless otherwise stated.

Cell culture and treatment. HLE-B3 cells were cultured in RPMI-1640 medium (HyClone; GE Healthcare Life Sciences, Logan, UT, USA) containing $1 \mathrm{~g} / 1$ glucose, $10 \%$ fetal bovine serum (HyClone; GE Healthcare Life Sciences), 100 U/ml penicillin and $100 \mu \mathrm{g} / \mathrm{ml}$ streptomycin (HyClone; GE Healthcare Life Sciences) under a humidified atmosphere with $5 \% \mathrm{CO}_{2}$ at $37^{\circ} \mathrm{C}$. The cells were seeded into a $60 \mathrm{~mm}$ culture dish (Corning Incorporated, Corning, NY, USA). When at 75-80\% confluence, the cells were treated with $\mathrm{H}_{2} \mathrm{O}_{2}(10-500 \mu \mathrm{M})$ for $24 \mathrm{~h}$ or pretreated with CGA for $2 \mathrm{~h}$ prior to $\mathrm{H}_{2} \mathrm{O}_{2}$-treatment. At the indicated time-points, the cells were collected for different assays.

Cell viability assay. The concentrations of CGA and $\mathrm{H}_{2} \mathrm{O}_{2}$ were optimized using MTT assay. Briefly, hLECs were cultured in 96-well plates and treated with a broad range of concentrations for each reagent $\left(\mathrm{H}_{2} \mathrm{O}_{2}\right.$ or CGA) for $24 \mathrm{~h}$. To examine the effect of CGA, hLECs were incubated with $100 \mu \mathrm{M} \mathrm{H}_{2} \mathrm{O}_{2}$ in the absence or presence of different concentrations of CGA for $24 \mathrm{~h}$. Subsequently, $20 \mu \mathrm{l}$ MTT solution $(5 \mathrm{mg} / \mathrm{ml}$ ) was added into each well. After another $4 \mathrm{~h}$ incubation at $37^{\circ} \mathrm{C}$, the medium was removed and the formazan crystals formed by oxidation of the MTT dye were dissolved with $150 \mu 1$ DMSO. The absorbance was measured at $490 \mathrm{~nm}$ using the spectrophotometer [Unico (shanghai) Science Instruments Co., Ltd., Shanghai, China]and the cell survival ratio was expressed as a percentage of the blank.

Measurement of intracellular reactive oxygen species (ROS). To obtain further evidence for the protective effect of CGA against $\mathrm{H}_{2} \mathrm{O}_{2}$ induced oxidative stress, alterations of intracellular ROS levels were determined. The production of intracellular ROS was measured using 2',7'-dichlorofluorescin diacetate (DCFH-DA; Invitrogen, Carlsbad, CA, USA) by flow cytometry. Briefly, hLECs were incubated either with $100 \mu \mathrm{M}$ $\mathrm{H}_{2} \mathrm{O}_{2}$ alone or treated with different concentrations (10, 30 and
Table I. Primer sequences for Bcl-2, Bax and GAPDH.

\begin{tabular}{lc}
\hline Target gene & \multicolumn{1}{c}{ Primer sequence } \\
\hline Bcl-2 & F: 5'-GAGTGGATGACCGTCTACCTG-3' \\
& R: 5'-CCTGAGACCTTCTGCTTTCG-3' \\
Bax & F: 5'-TTTTGCTTCAGGGTTTCATC-3' \\
& R: 5'-GACACTCGCTCAGCTTCTTG-3' \\
GAPDH & F:5'-CCATGTTCGTCATGGGTGTGAACCA-3' \\
& R:5-GCCAGTAGAGGCAGGGATGATGTTC-3'
\end{tabular}

Bcl-2, BCL2, apoptosis regulator; Bax, BCL2 associated X, apoptosis regulator; GAPDH, Glyceraldehyde-phosphate dehydrogenase.

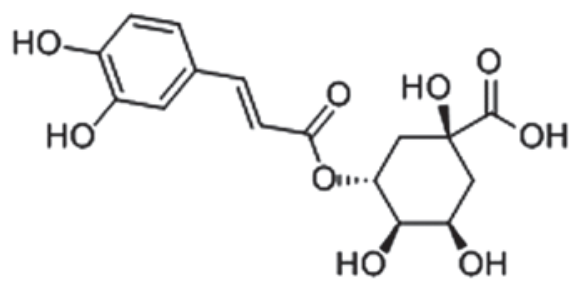

Figure 1. Molecular structure of chlorogenic acid.

$50 \mu \mathrm{M}$ ) of CGA for $2 \mathrm{~h}$ prior to treatment with $100 \mu \mathrm{M} \mathrm{H}_{2} \mathrm{O}_{2}$ for $24 \mathrm{~h}$. After harvest of hLECs, the cells were incubated with DCFH-DA solution $(10 \mu \mathrm{M})$ in the dark at $37^{\circ} \mathrm{C}$ for $30 \mathrm{~min}$, washed with PBS (pH 7.4), and analyzed within 30 min using a flow cytometer (Accuri C6; Accuri Cytometers Inc., Ann Arbor, MI, USA). The specific fluorescence signals that correspond to DCFH-DA were collected with a $525 \mathrm{~nm}$ band pass filter. For each determination, $2.0 \times 10^{4}$ cells were counted.

Apoptosis assay. For quantification of the apoptosis rate in hLECs, cells were cultured on a 6 -well plate at $5.0 \times 10^{5}$ cells/well and treated with $100 \mu \mathrm{M} \mathrm{H}_{2} \mathrm{O}_{2}$ with or without CGA $(0,10$, 30 and $50 \mu \mathrm{M}$ ) for $24 \mathrm{~h}$. Subsequently, hLECs were collected and stained using Annexin V/PI kit and assessed by a flow cytometer (Accuri C6; Accuri Cytometers), following the instructions of the manufacturer.

Revere transcription-quantitative polymerase chain reaction $(R T-q P C R)$. The effect of CGA on the gene expression of BCL2 associated X, apoptosis regulator (Bax) and BCL2, apoptosis regulator ( $\mathrm{Bcl}-2)$ mRNA using RT-qPCR in the presence and absence of $\mathrm{H}_{2} \mathrm{O}_{2}$. The cells $\left(6 \times 10^{5}\right)$ were incubated either with $100 \mu \mathrm{M} \mathrm{H}_{2} \mathrm{O}_{2}$ for $24 \mathrm{~h}$ or with CGA for $2 \mathrm{~h}$ prior to treatment with $100 \mu \mathrm{M} \mathrm{H}_{2} \mathrm{O}_{2}$. Total RNA was extracted with TRIzol reagent (Life Technologies; Thermo Fisher Scientific, Inc., Waltham, MA, USA) and cDNA was generated using a Superscript cDNA kit (Thermo Fisher Scientific, Inc.) based on the manufacturer's protocol. Following quantification with a micro-spectrophotometer (Beijing Kaiao Technology Development Co., Ltd., Beijing, China), cDNA was synthesized using total RNA. qPCR was performed with SYBR-Green Master Mix (Takara Biotechnology Co., Ltd., Dalian, China) in a Stratagene Mx3000P sequence detection system (Agilent Technologies, Inc., Santa Clara, CA, USA). GAPDH was 

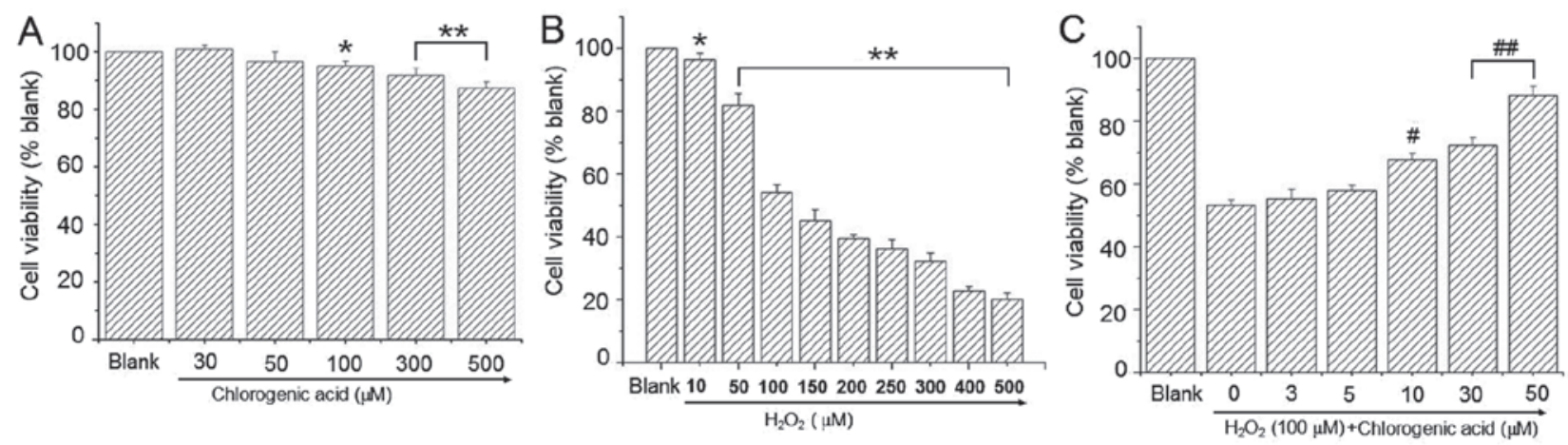

Figure 2. Cell viability was assessed by MTT assay. (A) Cells were treated with chlorogenic acid $(0-500 \mu \mathrm{M})$ for $24 \mathrm{~h}$. (B) Cells were treated with $\mathrm{H}_{2} \mathrm{O}_{2}$ $(0-500 \mu \mathrm{M})$ for $24 \mathrm{~h}$. (C) Effect of chlorogenic acid on HLE-B3 cell viability in co-treatment with $\mathrm{H}_{2} \mathrm{O}_{2}(100 \mu \mathrm{M})$. Blank cells were cultured in media alone, while control cells were treated with $\mathrm{H}_{2} \mathrm{O}_{2}(100 \mu \mathrm{M})$ alone. Data are presented as the mean + standard deviation. (" $\mathrm{P}<0.05$ and ${ }^{* *} \mathrm{P}<0.01$ vs. blank; ${ }^{*} \mathrm{P}<0.05$ and ${ }^{\# \prime} \mathrm{P}<0.01$ vs. control; one-way analysis of variance and followed by Tukey's honest significant difference post hoc test).

used as a positive control, and a negative control without template RNA was also included. The primer sequences are presented in Table I. The reactions were performed in a total volume of $20 \mu \mathrm{l}$ using the SensiMix One-Step kit (http://www. quantace.com; Quantace, Finchley, UK). The conditions of PCR amplification for Bcl-2 and Bax were as follows: $95^{\circ} \mathrm{C}$ for $10 \mathrm{~min}$, followed by 40 cycles of a $95^{\circ} \mathrm{C}$ denaturation for $15 \mathrm{sec}$, annealing at $55^{\circ} \mathrm{C}$ for $30 \mathrm{sec}$, and $72^{\circ} \mathrm{C}$ extension for $50 \mathrm{sec}$. Each experiment was carried out four times and the $\Delta \Delta \mathrm{Cq}$ values were calculated by normalizing the gene expression levels to the expression of GAPDH (25). The relative expression level of each gene was expressed as a fold change.

ELISA. The levels of Bcl-2/Bax (anti-/pro-apoptotic) proteins were determined using commercially available ELISA kits [BCL-2 kit (JYM0302Hu), BAX kit (JYM0265Hu); Colorfulgene Biological Technology, Co., Ltd., Wuhan, China]. The hLECs $\left(6 \times 10^{5}\right)$ were incubated with $100 \mu \mathrm{M} \mathrm{H}_{2} \mathrm{O}_{2}$ for $24 \mathrm{~h}$ alone or treated with CGA for $2 \mathrm{~h}$ prior to treatment with $100 \mu \mathrm{M}$ $\mathrm{H}_{2} \mathrm{O}_{2}$ for $24 \mathrm{~h}$. The cells were then collected and cell concentration was diluted to $10^{6} / \mathrm{ml}$ with PBS (pH 7.2-7.4). Following three freeze-thaw cycles, damaged cells were centrifuged at $5,000 \mathrm{x} \mathrm{g}$ at $4^{\circ} \mathrm{C}$ for $20 \mathrm{~min}$. The supernatant was carefully collected and stored at $-80^{\circ} \mathrm{C}$ prior to use. The protein in the cell lysate was determined using the ELISA kit according to the manufacturer's instructions. Subsequently, the plates were read at $450 \mathrm{~nm}$ using a microplate reader (BioTek ELX800; BioTek Instruments, Inc., Winooski, VT, USA). The protein level of each sample was determined by comparison to a standard curve.

Lens organ culture and treatment. All animal procedures were in accordance with the Association for Research in Vision and Ophthalmology Statement for the Use of Animals in Ophthalmic and Vision Research (26), and the animal experiments were approved by Shandong University of Traditional Chinese Medicine Animal Care and Ethics Committee (Jinan, China). In the present study, New Zealand White rabbits ( $\mathrm{n}=30$; weighing $1.8-2.0 \mathrm{~kg}$ ) aged 10-12 weeks were euthanized with an overdose of sodium pentobarbital injection through the marginal ear vein. The eyes were removed and the lenses were carefully dissected by a posterior approach. Lenses were immediately transferred into a 24-well culture plate containing $2 \mathrm{ml}$ Dulbecco's modified Eagle's medium (HyClone, Beijing, China), $1 \mathrm{~g} / \mathrm{l}$ glucose,
$100 \mathrm{U} / \mathrm{ml}$ penicillin and $100 \mu \mathrm{g} / \mathrm{ml}$ streptomycin (HyClone; GE Healthcare Life Sciences). Approximately, $24 \mathrm{~h}$ after the preparation of organ cultures, transparent lenses were selected for further experimentation. During the experiment, $\mathrm{H}_{2} \mathrm{O}_{2}$ and CGA were maintained at indicated concentrations for a period of $12 \mathrm{~h}$, and the medium was changed. Conditioned medium was stored for further culture. Lenses were cultured in a $5 \% \mathrm{CO}_{2}$ incubator at $37^{\circ} \mathrm{C}$ for $48 \mathrm{~h}$, and were images using a stereomicroscope under a cross background $(1.0 \times 1.0 \mathrm{~cm})$. Each sample contained three lenses and lens opacity was analyzed using ImageJ-1.46 software (National Institutes of Health, Bethesda, MD, USA). This experiment was repeated three times independently.

Flow cytometry with Annexin V/PI staining. The apoptosis rate of lens epithelial cells was assessed by flow cytometry with Annexin V/PI staining. The lenses exposed to $500 \mu \mathrm{M} \mathrm{H}_{2} \mathrm{O}_{2}$ were cultured with various concentrations (i.e., $0,10,30$ and $50 \mu \mathrm{M}$ ) of CGA for $48 \mathrm{~h}$. At the indicated time-points $(0,12,24$ and $48 \mathrm{~h}$, respectively), lens epithelial explants were carefully detached from rabbit lens under an operation microscope (YZ20P5; 66 Vision Tech Co., Ltd., Suzhou, China). Lens epithelial explants were then sheared, digested with trypsin, and RPMI-1640 medium was added to terminate the digestion (27). The cell suspension was then passed through a cell strainer and centrifuged $(300 \mathrm{x} \mathrm{g})$ at $4^{\circ} \mathrm{C}$ for $5 \mathrm{~min}$. The cells were resuspended in RPMI-1640 medium and collected by centrifugation at $300 \mathrm{x} \mathrm{g}$ at $4^{\circ} \mathrm{C}$ for $10 \mathrm{~min}$. The collected cells were washed with cold PBS and stained with Annexin V/PI apoptotic detection kit. Finally, the cells were resuspended in $500 \mu \mathrm{l}$ PBS for further analysis using a flow cytometer (Accuri C6; Accuri Cytometers, Inc.).

Statistical analysis. All experiments were repeated three times and data are expressed as the mean \pm standard deviation, and were analyzed by one-way analysis of variance, followed by Tukey's honest significant difference post hoc test, using SPSS software (version 17.0; SPSS Inc., Chicago, IL, USA). P<0.05 was considered to indicate a statistically significant difference.

\section{Results}

Cell viability assessed by MTT assay. To determine the effect of CGA on hLECs, cells were treated with a broad range of CGA concentrations for $24 \mathrm{~h}$. Cell viability was presented as a 
A

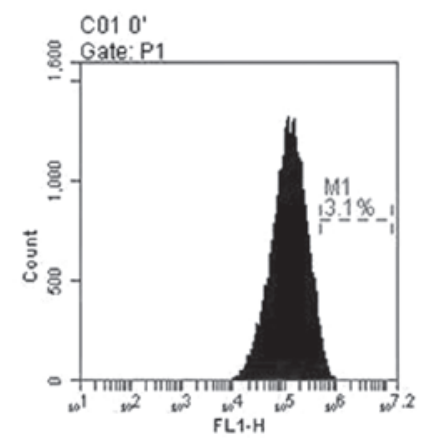

B F01

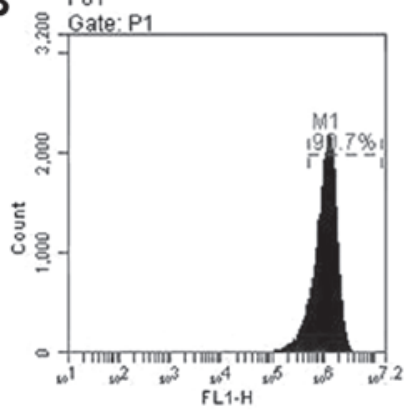

C

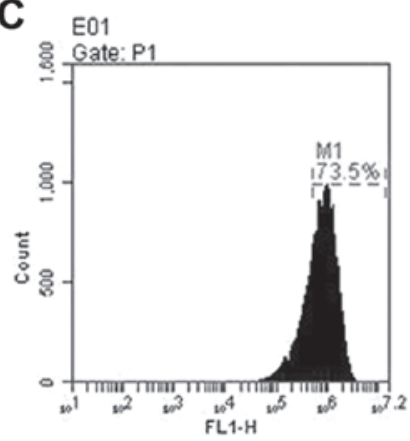

D $\quad$ E011 $\mathrm{min}$

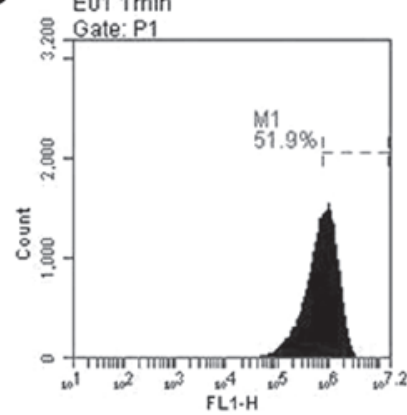

E

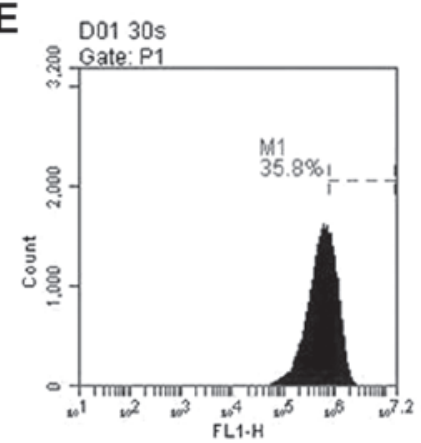

Figure 3. The alterations of ROS levels in human lens epithelial cells determined by flow cytometry. Cells were cultured following exposure to $100 \mu \mathrm{M} \mathrm{H}_{2} \mathrm{O}_{2}$ with or without CGA $(0,10,30$ and $50 \mu \mathrm{M})$ for $24 \mathrm{~h}$. (A) Untreated cells; (B) cells exposed to $100 \mu \mathrm{M} \mathrm{H}_{2} \mathrm{O}_{2}$; (C) cells exposed to $100 \mu \mathrm{M} \mathrm{H} \mathrm{H}_{2}+10 \mu \mathrm{M}$ CGA; (D) cells exposed to $100 \mu \mathrm{M} \mathrm{H}_{2} \mathrm{O}_{2}+30 \mu \mathrm{M} \mathrm{CGA}$; (E) cells exposed to $100 \mu \mathrm{M} \mathrm{H}_{2} \mathrm{O}_{2}+50 \mu \mathrm{M} \mathrm{CGA}$. Data re the percentage of cells producing ROS and are the mean value from three independent experiments performed by flow cytometry. ROS, reactive oxygen species; CGA, chlorogenic acid.
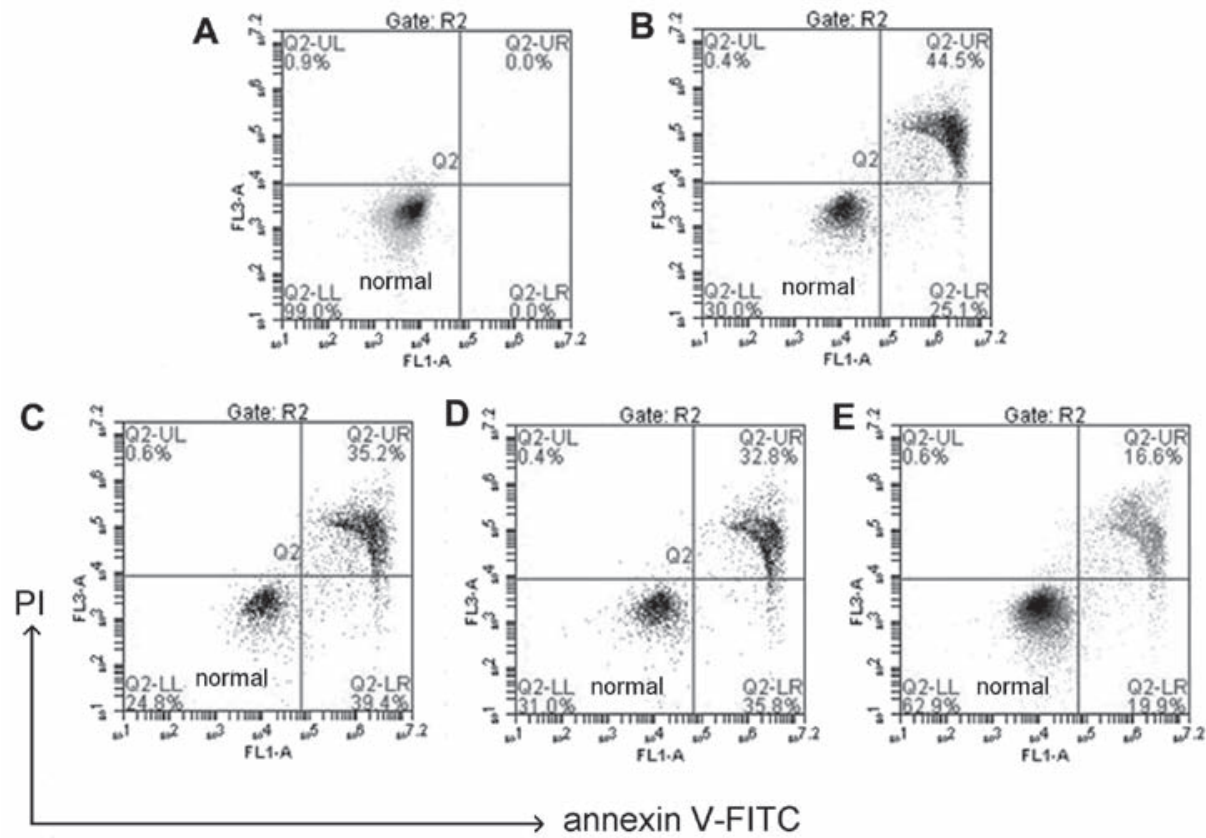

Figure 4. Apoptosis analysis of human lens epithelial cells. (A) Apoptosis in blank cells without any treatment, or pretreated with different concentration of chlorogenic acid: (B) $0 \mu \mathrm{M}$, (C) $10 \mu \mathrm{M}$, (D) $30 \mu \mathrm{M}$, (E) $50 \mu \mathrm{M}$, followed by $100 \mu \mathrm{M} \mathrm{H}_{2} \mathrm{O}_{2}$ for $24 \mathrm{~h}$. Apoptosis was analyzed using flow cytometry with Annexin V/PI staining. Control cells were treated with $\mathrm{H}_{2} \mathrm{O}_{2}(100 \mu \mathrm{M})$ alone. $\mathrm{P}<0.01$ control group vs. all other groups. PI, propidium iodide; FITC, fluorescein isothiocyanate.

percentage of the blank value. The results indicated that CGA had no cytotoxicity in hLEC cells when the CGA concentration was $<100 \mu \mathrm{M}$ (Fig. 2A). $\mathrm{H}_{2} \mathrm{O}_{2}$-treated cells exhibited lower cell viability at $\mathrm{H}_{2} \mathrm{O}_{2}$ concentrations $\geq 50 \mu \mathrm{M}$ (Fig. 2B). Co-treatment with CGA resulted in a dose-dependent reduction in cytotoxicity induced by $\mathrm{H}_{2} \mathrm{O}_{2}(100 \mu \mathrm{M}$; Fig. 2C).
Effect of CGA on intracellular ROS. hLECs treatment with $100 \mu \mathrm{M} \mathrm{H}_{2} \mathrm{O}_{2}$ alone for $24 \mathrm{~h}$ resulted in the production of ROS with a $\sim 3$-fold increase compared with $50 \mu \mathrm{M}$ CGA-treated cells (Fig. 3). Pretreatment with CGA prior to $\mathrm{H}_{2} \mathrm{O}_{2}$ exposure markedly reduced the ROS levels. When hLECs were treated with CGA $(0,10,30$ and $50 \mu \mathrm{M})$ for $2 \mathrm{~h}$ prior to treatment 


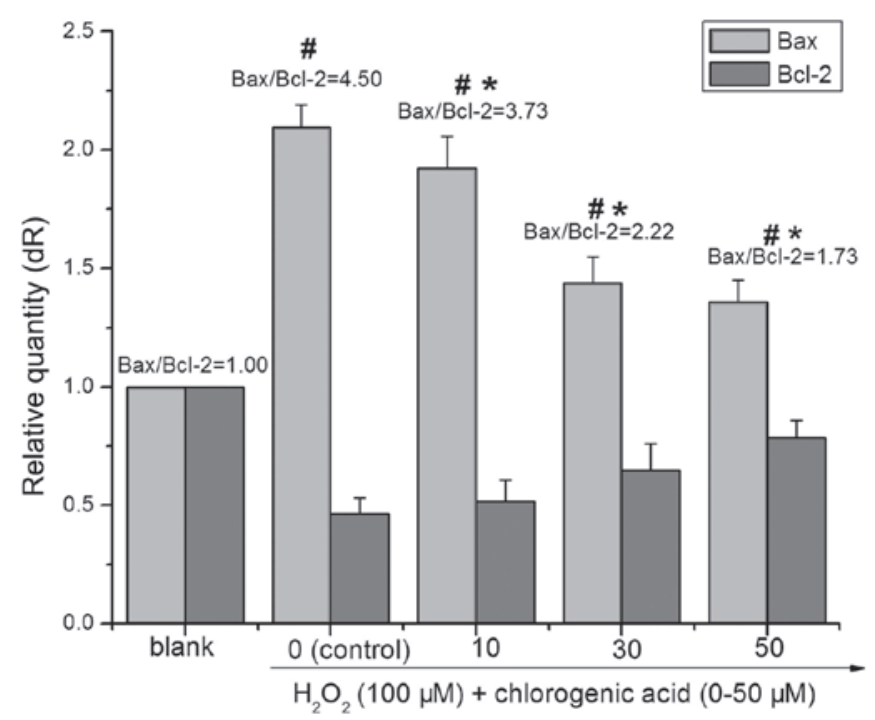

Figure 5. Bax and Bcl-2 mRNA were examined using reverse transcription-quantitative polymerase chain reaction. Changes in mRNA levels of either Bax or Bcl-2 after treatment with $100 \mu \mathrm{M} \mathrm{H}_{2} \mathrm{O}_{2}$ plus chlorogenic acid $(0$, 10,30 and $50 \mu \mathrm{M}$, respectively). Blank cells were cultured in media alone, while control cells were treated with $\mathrm{H}_{2} \mathrm{O}_{2}(100 \mu \mathrm{M})$ alone. Data are presented as the mean + standard deviation. ${ }^{*} \mathrm{P}<0.01$ vs. blank; ${ }^{2} \mathrm{P}<0.01$ vs. control, one-way analysis of variance and followed by Tukey's honest significant difference post hoc test). Bax, BCL2 associated X, apoptosis regulator; Bcl-2, BCL2, apoptosis regulator.
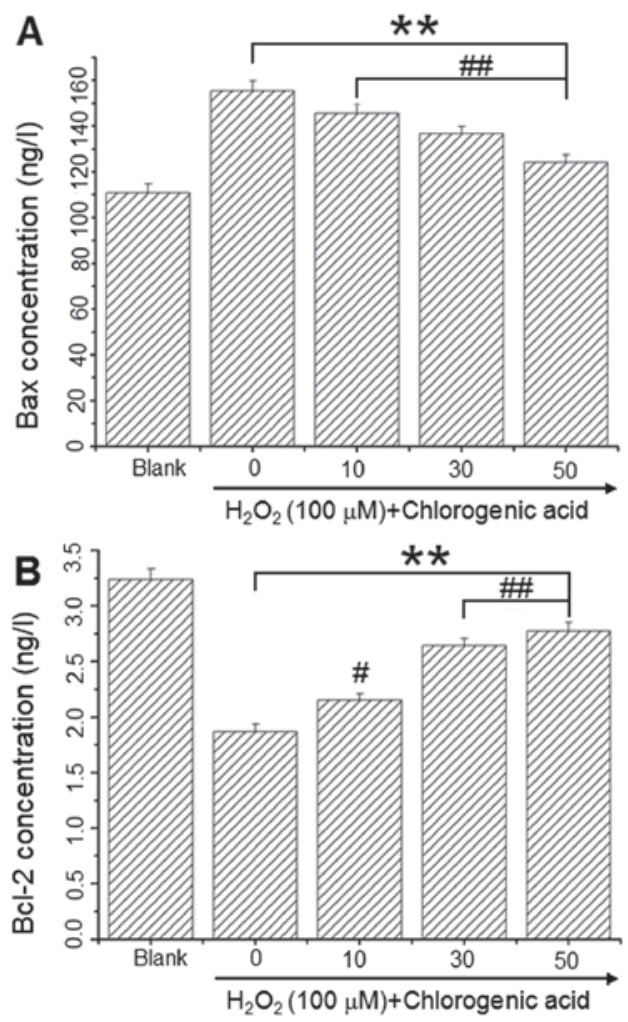

Figure 6. Determination of Bcl-2 and Bax protein expression using ELISA. (A) Protein level of Bax following treatment with $100 \mu \mathrm{M} \mathrm{H}_{2} \mathrm{O}_{2}$ plus chlorogenic acid $(0,10,30$ and $50 \mu \mathrm{M})$ for $24 \mathrm{~h}$. (B) Protein level of Bcl-2 following treatment $100 \mu \mathrm{M} \mathrm{H}_{2} \mathrm{O}_{2}$ plus chlorogenic acid (i.e., 0, 10, 30 and $50 \mu \mathrm{M}$ ) for $24 \mathrm{~h}$. Blank cells were cultured in medium alone. Control cells were treated with $\mathrm{H}_{2} \mathrm{O}_{2}(100 \mu \mathrm{M})$ alone. Data are expressed as the mean \pm standard deviation. $\left({ }^{*} \mathrm{P}<0.05\right.$ and ${ }^{* *} \mathrm{P}<0.01$ vs. blank; ${ }^{\#} \mathrm{P}<0.01$ and ${ }^{\#} \mathrm{P}<0.05$ vs. control, one-way analysis of variance and followed by Tukey's honest significant difference post hoc test). Bax, BCL2 associated X, apoptosis regulator; Bcl-2, BCL2 apoptosis regulator.


Figure 7. Effect of $\mathrm{H}_{2} \mathrm{O}_{2}$ and/or chlorogenic acid on the transparency of rabbit lens. Rabbit lenses were treated untreated (I) or treated with $500 \mu \mathrm{M} \mathrm{H}_{2} \mathrm{O}_{2}$ plus different concentrations of chlorogenic acid [0 $\mu \mathrm{M}$ (II), $10 \mu \mathrm{M}$ (III), $30 \mu \mathrm{M}(\mathrm{IV}), 50 \mu \mathrm{M}(\mathrm{V})]$ and were images with a cross background $(1.0 \times 1.0 \mathrm{~cm})$ at indicated time-points $(12,24$ and $48 \mathrm{~h}$, respectively).

with $100 \mu \mathrm{M} \mathrm{H}_{2} \mathrm{O}_{2}$ for $24 \mathrm{~h}$, the ROS generation reduced from $90.7 \pm 7.75$ to $73.5 \pm 5.98 \%, 51.9 \pm 4.74$ and $35.8 \pm 3.53 \%$ (Fig. 3B-E), respectively. These findings demonstrated that with the increase of concentrations of CGA, the intracellular ROS level induced by $\mathrm{H}_{2} \mathrm{O}_{2}$ was reduced and the ROS reduction was in a concentration-dependent manner. In addition, there was a significant difference in the level of $\mathrm{H}_{2} \mathrm{O}_{2}$-induced ROS compared with that of untreated cells (Fig. 3).

CGA prevents $\mathrm{H}_{2} \mathrm{O}_{2}$-induced apoptotic changes in hLECs. The use of Annexin V/PI double staining allows distinction between live cell populations, cells entering early apoptosis and those in late-stage apoptosis/necrosis. Q2-LL quadrant indicates healthy cells, Q2-UR quadrant indicates necrosis cells (Fig. 4). Any late-stage apoptosis cells were considered as necrosis as this technique is not sensitive enough to differentiate between the two. The data in Fig. 4 demonstrated that following treatment with $100 \mu \mathrm{M} \mathrm{H}_{2} \mathrm{O}_{2}$ and co-treatment with CGA $(10,30$ and $50 \mu \mathrm{M})$ for $24 \mathrm{~h}$, the late apoptotic rate of HLE-B3 cells decreased from 44.5 to $35.2,32.8$ and $16.6 \%$, respectively (Fig. 4).

CGA modulates the expression of Bcl-2/Bax. The members of the $\mathrm{Bcl}-2$ protein family are pivotal role in the regulation of the mitochondrial apoptotic pathway (28). Both pro-apoptotic and anti-apoptotic Bcl-2 family members can affect the execution of apoptosis. As presented in Fig. 5, treatment with $100 \mu \mathrm{M}$ $\mathrm{H}_{2} \mathrm{O}_{2}$ for $24 \mathrm{~h}$ decreased the expression of Bcl-2 (0.47-fold higher compared with blank) and increased the expression of Bax (2.09-fold higher compared with blank), whereas pretreatment with CGA inhibited the downregulation of Bcl-2 and upregulation of Bax. The ratio of $\mathrm{Bax} / \mathrm{Bcl}-2$ in the $100 \mu \mathrm{M}$ $\mathrm{H}_{2} \mathrm{O}_{2}$-treated group was significantly higher than that in the blank group $(\mathrm{P}<0.01)$. With elevated CGA concentrations, the ratio of $\mathrm{Bax} / \mathrm{Bcl}-2$ in the CGA-treated (i.e., 10, 30 and $50 \mu \mathrm{M}$ ) groups decreased significantly compared with the $\mathrm{H}_{2} \mathrm{O}_{2}$-treated group $(\mathrm{P}<0.01)$. Following treatment with $100 \mu \mathrm{M} \mathrm{H}_{2} \mathrm{O}_{2}$ and co-treatment with different concentrations of CGA $(10,30$ 

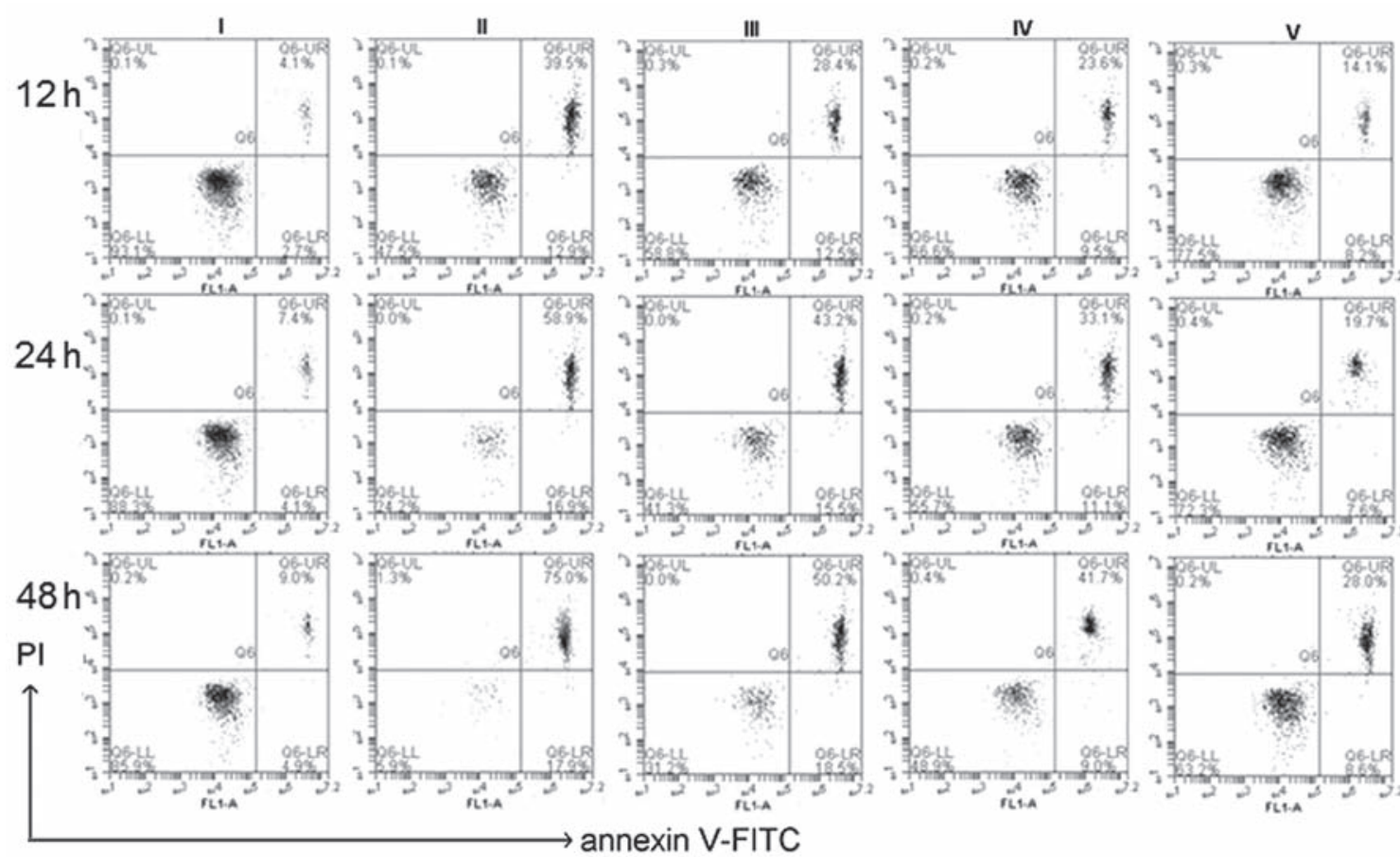

Figure 8. Apoptotic analysis of isolated lens epithelial cells by flow cytometry after staining with Annexin V/PI. Cells were treated untreated (blank; I) or treated with $500 \mu \mathrm{M} \mathrm{H}_{2} \mathrm{O}_{2}$ (control) plus different concentrations of chlorogenic acid [0 $\mu \mathrm{M}$ (II), $10 \mu \mathrm{M}$ (III), $30 \mu \mathrm{M}$ (IV), $50 \mu \mathrm{M}$ (V)]. At the indicated time-points (i.e., 12, 24 and $48 \mathrm{~h}$ ), the apoptosis rates were (II): 51.8 $\pm 3.81,77.2 \pm 4.12$ and $94.57 \pm 4.77 \%$; (III): $42.3 \pm 3.76,58.3 \pm 3.67$ and $65.9 \pm 4.12 \%$; (IV): $33.7 \pm 2.95,42.3 \pm 3.29$ and $50.43 \pm 4.13 \%$; (V): $22.4 \pm 1.09,28.5 \pm 2.54$ and $39.2 \pm 3.71 \%$ of control value. Data are expressed as the mean \pm standard deviation $\mathrm{P}<0.01$ blank vs. II, III, IV, V; P $<0.01$ control vs. I, III, IV, V; one-way analysis of variance and followed by Tukey's honest significant difference post hoc test). $\mathrm{PI}$, propidium iodide; FITC, fluorescein isothiocyanate.

and $50 \mu \mathrm{M}$ ) for $24 \mathrm{~h}$ the ratios of $\mathrm{Bax} / \mathrm{Bcl}-2$ were $4.50 \pm 0.61$, $3.73 \pm 0.46,2.22 \pm 0.47$ and $1.73 \pm 0.33$, respectively.

CGA downregulates Bcl-2 expression and upregulates Bax expression. Bcl-2 and Bax levels were assessed using commercially available ELISA kits to determine whether these key regulators of apoptosis were involved in the $\mathrm{H}_{2} \mathrm{O}_{2}$-induced apoptosis mechanism. As presented in Fig. 5, Bax protein levels were $110.91 \pm 3.97,155.49 \pm 4.30,145.59 \pm 4.17,136.78 \pm 3.07$ and $124.19 \pm 3.11 \mathrm{ng} / \mathrm{l}$ (Fig. 6A) and Bcl-2 levels were 3.24 \pm 0.10 , $1.87 \pm 0.07,2.15 \pm 0.06,2.64 \pm 0.09$ and $2.77 \pm 0.10 \mathrm{ng} / \mathrm{l}$ (Fig. 6B) in the blank, $100 \mu \mathrm{M} \mathrm{H}_{2} \mathrm{O}_{2}$ and $\mathrm{H}_{2} \mathrm{O}_{2}+\mathrm{CGA} 10,30$ and $50 \mu \mathrm{M}$ groups, respectively. These results demonstrated that CGA increased $\mathrm{Bcl}-2$ protein expression and decreased Bax protein expression in hLECs following incubation with $100 \mu \mathrm{M} \mathrm{H}_{2} \mathrm{O}_{2}$ for $24 \mathrm{~h}$.

CGA prevents $\mathrm{H}_{2} \mathrm{O}_{2}$-induced lens opacity. The protective effects of CGA against cataractogenesis of rabbit lenses induced with $\mathrm{H}_{2} \mathrm{O}_{2}(500 \mu \mathrm{M})$ were investigated further. As presented in Fig. 7, loss of transparency in lenses exposed to $500 \mu \mathrm{M} \mathrm{H}_{2} \mathrm{O}_{2}$ was first noted in the equatorial region, spreading throughout the superficial cortex by $24 \mathrm{~h}$ and into deeper regions by $48 \mathrm{~h}$. By contrast, there was little change in transparency of untreated lenses during the entire exposure period. The opacities of rabbit lenses incubated in $\mathrm{H}_{2} \mathrm{O}_{2}(500 \mu \mathrm{M})$ media containing various concentrations of CGA were measured every $12 \mathrm{~h}$ and compared with the control and blank samples. The opacities of the lenses began to increase after $12 \mathrm{~h}$ treatment with $\mathrm{H}_{2} \mathrm{O}_{2}$, and were gradually improved by CGA treatment in a dose-dependent manner.
At the indicated time-point, lens epithelial explants were detached. LECs were harvested and stained with Annexin V/PI for further analysis using a flow cytometer. Lenses treated with $500 \mu \mathrm{M} \mathrm{H}_{2} \mathrm{O}_{2}$ for 12,24 and $48 \mathrm{~h}$, caused a time-dependent increase of apoptosis rates $(51.8 \pm 3.81$, $77.2 \pm 4.12$ and $94.57 \pm 4.77 \%$ of control value, respectively) whereas co-treatment with different concentrations of CGA [10 $\mu \mathrm{M}$ (III), $30 \mu \mathrm{M}$ (IV), $50 \mu \mathrm{M}(\mathrm{V})]$ the decreased the apoptosis rates (Fig. 8).

\section{Discussion}

As the most anterior part of the lens, LECs are the primary site of external insult that ultimately leads to cataracts (29). LECs are also the most metabolically-active part of the lens and are responsible for maintaining homeostasis and transparency. Li et al (3) have reported that apoptosis in lens epithelium may be a common cellular basis for noncongenital cataract formation, and that blocking apoptosis may prevent cataract formation. To investigate the protective effects of CGA on $\mathrm{H}_{2} \mathrm{O}_{2}$-induced apoptosis in hLECs, we performed a dose-response experiment using a range of concentrations (10, 30 and $50 \mu \mathrm{M}) \cdot \mathrm{H}_{2} \mathrm{O}_{2}$ was used as the oxidant model of classical oxidative stress. The results demonstrated that all concentrations of CGA exerted a protective effect against oxidative stress and an inhibitory effect against apoptosis, as measured by the cell morphology and cell viability studies. In addition, CGA inhibited cytotoxicity in hLECs caused by $100 \mu \mathrm{M} \mathrm{H}_{2} \mathrm{O}_{2}$ compared with $\mathrm{H}_{2} \mathrm{O}_{2}$ treatment alone. Apoptosis is an intracellular suicide mechanism that cause morphologic 
changes and biochemical responses. In the presence of CGA, the proportions of apoptotic cells were significantly decreased. Thus, it is suggested that CGA may have a potentially beneficial role in the prevention of cataract formation.

It is well established that the proto-oncogene $\mathrm{Bcl}-2$ can prevent apoptosis induced by a variety of factors. Regarding the mechanism by which Bcl-2 prevents cell death, one theory suggests that it acts by protecting cells from oxidative stress. Mao et al (30) reported that through downregulation of the $\alpha \mathrm{B}$-crystallin gene, $\mathrm{Bcl}-2$ reduces the tolerance of rabbit lens epithelial cells against $\mathrm{H}_{2} \mathrm{O}_{2}$-induced apoptosis. Bcl-2 and Bax proteins are widely regarded as the most important apoptotic regulators, and their relative levels determine the fate of cells. Bcl-2 protein expression in the mitochondrial outer membrane inhibits cytochrome translocation into the cytosol, which is a critical step in the apoptotic process. By contrast, Bax is a pro-apoptotic antagonist of Bcl-2, and has been characterized as a Bcl-2 binding protein that shares significant sequence homology with Bcl-2 (31). An altered ratio of anti-apoptotic to pro-apoptotic Bcl-2 family genes is critical in determining whether apoptosis is performed. In the current study, RT-qPCR analysis revealed that the Bax/ Bcl-2 ratio was significantly increased by the treatment with $100 \mu \mathrm{M} \mathrm{H}_{2} \mathrm{O}_{2}$, and this increase was inhibited by pretreatment with CGA $(10,30$ and $50 \mu \mathrm{M})$. This result indicates that the Bcl-2 family may have a critical role in regulating hLEC death induced by $\mathrm{H}_{2} \mathrm{O}_{2}$, and that CGA is able to protect against $\mathrm{H}_{2} \mathrm{O}_{2}$-stimulated apoptosis through modulation of $\mathrm{Bax} / \mathrm{Bcl}-2$ expression.

Rabbit lenses were cultured ex vivo in an attempt to mimic the potential in vivo pathological environment present in patients with cataracts (12). Superoxide damages the lens, leading to loss of transparency and the formation of a cataract in vivo and ex vivo. Charakidas et al (32) suggested that the accumulation of small-scale epithelial losses during a lifetime may induce alterations in lens fiber formation and homeostasis, resulting in loss of lens transparency. Therefore, it is important to develop protective strategies for apoptosis of hLECs. As demonstrated in the current study, damage to lenses exposed to $\mathrm{H}_{2} \mathrm{O}_{2}$ ex vivo was initially observed in the equatorial region, spreading throughout the superficial cortex by $24 \mathrm{~h}$ and into the deeper regions by $48 \mathrm{~h}$. The $\mathrm{H}_{2} \mathrm{O}_{2}$-induced opacity of lenses was improved following treatment with CGA. Evidence from these ex vivo experiments indicated that the observed lens opacity can be induced by oxidative stress, and can be ameliorated by CGA.

In conclusion, the present study demonstrates that $\mathrm{H}_{2} \mathrm{O}_{2}$ can induce human lens epithelial cell apoptosis and lens opacification, whereas CGA can effectively attenuate human lens epithelial cell apoptosis and lens opacity under oxidative stress mediated by $\mathrm{H}_{2} \mathrm{O}_{2}$. CGA, a potent antioxidant, can effectively protect HLE-B3 cells against $\mathrm{H}_{2} \mathrm{O}_{2}$-induced oxidative stress and apoptosis via Bcl-2/Bax signaling pathway, suggesting that CGA may be applied clinically as a potential protective treatment for cataract formation.

\section{Acknowledgements}

This study was supported by the National Natural Science Foundation of China (grant nos. 81403438 and 81001577), and the Natural Science Foundation of Shandong province (grant nos. ZR2014HP059 and ZR2014HL048).

\section{References}

1. Long AC, Colitz CM and Bomser JA: Apoptotic and necrotic mechanisms of stress-induced human lens epithelial cell death. Exp Biol Med (Maywood) 229: 1072-1080, 2004

2. Kasai H, Fukada S, Yamaizumi Z, Sugie S and Mori H: Action of chlorogenic acid in vegetables and fruits as an inhibitor of 8-hydroxydeoxyguanosine formation in vitro and in a rat carcinogenesis model. Food Chem Toxicol 38: 467-471, 2000.

3. Li SY, Chang CQ, Ma FY and Yu CL: Modulating effects of chlorogenic acid on lipids and glucose metabolism and expression of hepatic peroxisome proliferator-activated receptor-alpha in golden hamsters fed on high fat diet. Biomed Environ Sci 22: 122-129, 2009.

4. Surveswaran S, Cai YZ, Xing J, Corke H and Sun M: Antioxidant properties and principal phenolic phytochemicals of Indian medicinal plants from Asclepiadoideae and Periplocoideae. Nat Prod Res 24: 206-221, 2010.

5. Truscott RJ: Age-related nuclear cataract-oxidation is the key. Exp Eye Res 80: 709-725, 2005.

6. Varma SD, Devamanoharan PS and Morris SM: Prevention of cataracts by nutritional and metabolic antioxidants. Crit Rev Food Sci Nutr 35: 111-129, 1995.

7. Gupta SK, Trivedi D, Srivastava S, Joshi S, Halder N and Verma SD: Lycopene attenuates oxidative stress induced experimental cataract development: An in vitro and in vivo study. Nutrition 19: 794-799, 2003.

8. Spector A: Oxidative stress-induced cataract: Mechanism of action. FASEB J 9: 1173-1182, 1995.

9. Spector A, Wang GM, Wang RR, Li WC and Kleiman NJ: A brief photochemically induced oxidative insult causes irreversible lens damage and cataract. II. Mechanism of action. Exp Eye Res 60: 483-493, 1995.

10. Csukas S, Costarides A, Riley MV and Green K: Hydrogen peroxide in the rabbit anterior chamber: Effects on glutathione, and catalase effects on peroxide kinetics. Curr Eye Res 6: 1395-1402, 1987.

11. Spector A, Ma W, Sun F, Li D and Kleiman NJ: The effect of $\mathrm{H}_{2} \mathrm{O}_{2}$ and tertiary butyl hydroperoxide upon a murine immortal lens epithelial cell line, alphaTN4-1. Exp Eye Res 75: 573-582, 2002.

12. Spector A and Garner WH: Hydrogen peroxide and human cataract. Exp Eye Res 33: 673-681, 1981.

13. Reddan JR, Giblin FJ, Dziedzic DC, Wirebaugh BM and Peters JL: Hydrogen peroxide affects specific epithelial subpopulations in cultured rabbit lenses. Invest Ophthalmol Vis Sci 36: 289-299, 1995.

14. Jia Z, Song Z, Zhao Y, Wang X and Liu P: Grape seed proanthocyanidin extract protects human lens epithelial cells from oxidative stress via reducing NF-кB and MAPK protein expression. Mol Vis 17: 210-217, 2011.

15. Tang X, Yao K, Zhang L, Yang Y and Yao H: Honokiol inhibits $\mathrm{H}(2) \mathrm{O}(2)$-induced apoptosis in human lens epithelial cells via inhibition of the mitogen-activated protein kinase and Akt pathways. Eur J Pharmacol 650: 72-78, 2011.

16. Yang J, Cai L, Zhang S, Zhu X, Zhou P and Lu Y: Silica-based cerium (III) chloride nanoparticles prevent the fructose-induced glycation of $\alpha$-crystallin and $\mathrm{H}_{2} \mathrm{O}_{2}$-induced oxidative stress in human lens epithelial cells. Arch Pharm Res 37: 404-411, 2014.

17. Gugliucci A and Bastos DH: Chlorogenic acid protects paraoxonase 1 activity in high density lipoprotein from inactivation caused by physiological concentrations of hypochlorite. Fitoterapia 80: 138-142, 2009.

18. Gugliucci A, Bastos DH, Schulze J and Souza MF: Caffeic and chlorogenic acids in Ilex paraguariensis extracts are the main inhibitors of AGE generation by methylglyoxal in model proteins. Fitoterapia 80: 339-344, 2009.

19. Kim C, Yu HG and Sohn J: The anti-angiogenic effect of chlorogenic acid on choroidal neovascularization. Korean J Ophthalmol 24: 163-168, 2010.

20. Li WC, Kuszak JR, Dunn K, Wang RR, Ma W, Wang GM, Spector A, Leib M, Cotliar AM, Weiss M, et al: Lens epithelial cell apoptosis appears to be a common cellular basis for non-congenital cataract development in humans and animals. J Cell Biol 130: 169-181, 1995. 
21. Spector A, Wang GM, Wang RR, Li WC and Kuszak JR: A brief photochemically induced oxidative insult causes irreversible lens damage and cataract. I. Transparency and epithelial cell layer. Exp Eye Res 60: 471-481, 1995c.

22. Kim YS, Kim NH, Lee YM and Kim JS: Preventive effect of chlorogenic acid on lens opacity and cytotoxicity in human lens epithelial cells. Biol Pharm Bull 34: 925-928, 2011.

23. Akila P and Vennila L: Chlorogenic acid a dietary polyphenol attenuates isoproterenol induced myocardial oxidative stress in rat myocardium: An in vivo study. Biomed Pharmacother 84: 208-214, 2016.

24. Ye HY, Li ZY, Zheng Y, Chen Y, Zhou ZH and Jin J: The attenuation of chlorogenic acid on oxidative stress for renal injury in streptozotocin-induced diabetic nephropathy rats. Arch Pharm Res 39: 989-997, 2016.

25. Livak KJ and Schmittgen TD: Analysis of relative gene expression data using real-time quantitative PCR and the 2(-Delta Delta C(T)) Method. Methods 25: 402-408, 2001.

26. Guide for Care and Use of Laboratory Animals. NIH Publication No. 80-23. Washington, D.C., National Academy Press, 1996.

27. Koushan SS, Behzad B, Masoumeh M, Vahid K, Fatemeh ZS Studies on the cytotoxic activities of Punica granatum L. var. spinosa (apple punice) extract on prostate cell line by induction of apoptosis. ISRN Pharm 2012: 1-6, 2012.

28. Burlacu A: Regulation of apoptosis by $\mathrm{Bcl}-2$ family proteins. J Cell Mol Med 7: 249-257, 2003.
29. Wu ZM, Yin XX, Ji L, Gao YY, Pan YM, Lu Q and Wang JY: Ginkgo biloba extract prevents against apoptosis induced by high glucose in human lens epithelial cells. Acta Pharmacol Sin 29: 1042-1050, 2008.

30. Mao YW, Xiang H, Wang J, Korsmeyer S, Reddan J and Li DW: Human bcl-2 gene attenuates the ability of rabbit lens epithelial cells against $\mathrm{H}_{2} \mathrm{O}_{2}$-induced apoptosis through down-regulation of the $\alpha$ B-crystallin gene. J Biol Chem 276: 43435-43445, 2001

31. Soluk Tekkeşın M, Mutlu S and Olgaç V: Expressions of bax, bcl-2 and Ki-67 in odontogenic keratocysts (Keratocystic Odontogenic Tumor) in comparison with ameloblastomas and radicular cysts. Turk Patoloji Derg 28: 49-55, 2012.

32. Charakidas A, Kalogeraki A, Tsilimbaris M, Koukoulomatis P, Brouzas D and Delides G: Lens epithelial apoptosis and cell proliferation in human age-related cortical cataract. Eur J Ophthalmol 15: 213-220, 2005 Attribution-NonCommercial-NoDerivatives 4.0 International (CC BY-NC-ND 4.0) License. 